\title{
ARTIKEL PENELITIAN \\ PENGARUH PEMBERIAN EKSTRAK PEPAYA TERHADAP KADAR KOLESTEROL TOTAL, LDL DAN HDL DARAH TIKUS PUTIH JANTAN HIPERKOLESTEROLEMIA
}

\author{
Endrinaldi, Asterina \\ Bagian Kimia Fakultas Kedokteran Universitas Andalas \\ email : endrinaldi29@yahoo.co.id
}

\begin{abstract}
Abstrak
Pepaya mengandung pektin yang merupakan serat larut air. Pektin berkemampuan mengikat asam empedu dan dieliminasi keluar tubuh melalui feses. Penurunan jumlah asam empedu di lumen usus menyebabkan hepar menggunakan kolesterol dalam darah untuk membentuk asam empedu. Hal tersebut mengakibatkan penurunan jumlah kolesterol.

Tujuan studi ini adalah untuk melihat pengaruh pemberian ekstrak pepaya mengkal terhadap kadar kolesterol total, HDL dan LDL tikus putih. Desain penelitian ini adalah eksperimental menggunakan 20 ekor tikus putih jantan yang dibagi menjadi empat kelompok, yaitu kelompok kontrol, dan kelompok perlakuan dengan pemberian ekstrak pepaya dengan dosis $0,5 \mathrm{ml}, 1 \mathrm{ml}$ dan $1,5 \mathrm{ml}$ per $200 \mathrm{~g} / \mathrm{BB}$ melalui oral selama 15 hari.

Hasil penelitian menunjukkan terjadinya penurunan rerata kadar kolesterol total, LDL, dan peningkatan kadar HDL serum tikus setelah pemberian ekstrak pepaya selama 15 hari secara bermakna $(\mathrm{p}<0,05)$. Tetapi tidak terjadi perbedaan yang bermakna $(\mathrm{p}>0,05)$ antara kelompok yang diberi ekstrak pepaya dengan dosis 0,5 $\mathrm{ml}, 1 \mathrm{ml}$, dan $1,5 \mathrm{ml}$.

Kesimpulan yang dapat diambil dari studi ini ialah bahwa ekstrak pepaya dapat menurunkan kadar kolesterol total, LDL, dan peningkatan kadar HDL pada serum tikus putih jantan
\end{abstract}

Kata kunci : pektin, kolesterol, asam empedu, serat, tikus.

Abstract

Papaya contain pectin which is a water-soluble fiber. Pectin has the ablity to bind bile acids and eliminated out of the body through the feces. Decrease in the amount of bile acids in intestinal lumen causing liver uses cholesterol to synthesize bile acids blood.

The purpose of this study was to see the effect of papaya extract on total cholesterol, HDL and LDL of male rats. This is an experimental research design using 20 white male rats were divided into four groups : control group and group treated with papaya extract a dose of $0,5 \mathrm{ml}, 1 \mathrm{ml}$ per $200 \mathrm{gr} /$ body weight orally for 15 days.

Results showed a decrease in everage total cholesterol, LDL and increased serum levels of rats after administration of papaya extract after 15 days were 
significantly $(\mathrm{p}<0,05)$. But no significantly difference occused $(\mathrm{p}>0,05)$ between groups were fed papaya extractat a dose of $0,5 \mathrm{ml}, 1 \mathrm{ml}$ and $1,5 \mathrm{ml}$.

Conclusions from the study are that papaya extract can lower total cholesterol, LDL and levels increased in the serum of male rats

Key word : pectin, cholesterol, bile acid, fiber, rats. 


\section{Pendahuluan}

Kolesterol merupakan derivat lipid yang tergolong steroid. Dalam darah terdapat dalam dua bentuk. Dua pertiganya dalam bentuk teresterifikasi dengan asam lemak dan sepertiganya dalam bentuk kolesterol bebas. Kadar kolesterol dalam tubuh tergantung pada keseimbangan asupan dari makanan, sintesis dalam jaringan dan ekskresinya dalam heapr. Efek buruk dari kolesterol adalah mempercepat proses aterosklerosis di pembuluh darah sehingga pembuluh darah akan menebal, kaku dan mudah tersumbat. ${ }^{(1)}$

Aterosklerosis merupakan penyakit yang dapat menyebabkan infark miokardium dan stroke. Faktor utama aterosklerosis adalah peningkatan kadar kolesterol dalam plasma/serum, lebih spesifik lagi adalah rasio kolesterol HDL : LDL. Pengobatan atau penurunan agar mempertahankan kadar kolesterol normal adalah dengan menggunakan terapi obat-obatan kimia yang dikonsumsi dalam jangka waktu lama akan menimbulkan efek yang lebih berbahaya. Untuk itu perlu dicari obat alternatif yang relatif aman.

Salah satu buah-buahan yang mengandung serat tinggi yang dapat menormalkan tekanan darah adalah buah papaya. Buah pepaya banyak mengandung zat-zat kimia yang bermanfaat bagi tubuh, terutama pada pembuluh darah. Buah papaya kaya akan vitamin A ( $\beta$-Karoten), vitamin $C$, pektin dan enzim papain. ${ }^{(2,3)}$

Pektin merupakan serat makanan, yang memiliki kemampuan membentuk gel dengan ion-ion, juga dapat menurunkan absorpsi kolesterol. Pektin bersifat mengikat dan meningkatkan pengeluaran asam empedu yang kemudian akan terbuang bersama-sama feses. Pengikatan asam empedu oleh pektin menyebabkan asam empedu keluar dari siklus enterohepatik. Penurunan jumlah asam empedu menyebabkan hepar menggunakan kolesterol dalam darah sebagai bahan untuk membentuk asam empedu. Peningkatan asam empedu feses atau kolesterol yang hilang dapat menyebabkan penurunan kolesterol plasma, dan meningkatkan biosintesis turnover kolesterol pada hewan coba. ${ }^{(4-}$ 6)

Adanya kandungan pektin dalam pepaya diduga akan dapat berfungsi menurunkan kadar kolesterol darah. Hal ini akan menimbulkan pertanyaan apakah ekstrak papaya dapat menurunkan kadar kolesterol darah pada hewan coba yang hiperkolesterolemia ?.

Penelitian ini bertujuan untuk mendapatkan data apakah buah pepaya dapat berkhasiat sebagai anti hiperkolesterolemia. Disamping itu hasil penelitian diharapkan menjadi pedoman bagi masyarakat apakah ekstrak pepaya dapat dijadikan sebagai obat untuk menurunkan kolesterol darah.

\section{METODE PENELITIAN}

A. Rancangan Penelitian

Penelitian bersifat eksperimental, sampel penelitian adalah tikus putih jantan berumur dua sampai tiga bulan dengan berat badan antara $200-300$ gram. Tikus yang digunakan untuk penelitian ini sebanyak 20 ekor, tikus ini diaklimatisasi dalam kondisi laboratorium selama satu minggu dengan diberi makanan dan minuman yang cukup. Tikus dinaikan kolesterol darahnya dengan cara memberikan kuning telur secara oral $2 \mathrm{ml} / 200$ gr BB/hari selama 15 hari. Diukur kadar kolesterol total, LDL dan HDL.

Selanjutnya tikus dibagi menjadi empat kelompok yang terdiri dari 5 ekor.

Kelompok I (K) : Sebagai kelompok kontrol negatif tanpa diberi ekstrak pepaya.

Kelompok II (P1) : Diberi ekstrak pepaya dengan dosis $0,5 \mathrm{ml} / 200 \mathrm{grBB}$. 
Kelompok III (P2) : Diberi ekstrak pepaya dengan dosis $1 \mathrm{ml} / 200 \mathrm{grBB}$.

Kelompok IV (P3) : Diberi ekstrak pepaya dengan dosis $1,5 \mathrm{ml} / 200 \mathrm{grBB}$.

Pemberian ekstrak pepaya dilakukan secara oral selama 15 hari. Pada hari ke 16 tikus ditimbang dan diambil darahnya, kemudian diiukur kadar kolesterol total, LDL dan HDL. Selama perlakuan tikus diberi makanan standar, kuning telur dan air minum ad libitum.

\section{B. Cara pembuatan ekstrak papaya}

Buah pepaya mengkal dibersihkan, dikupas kulitnya, ambil $1 \mathrm{~kg}$ kemudian potong-potong, masukan ke dalam blender dan tambahkan air kemudian diblender. Dibiarkan beberapa jam, kemudian diperas dengan kain. Sari papaya diuapkan pada suhu $75^{\circ} \mathrm{C}$ sampai laruran kering. Ekstrak diencerkan dengan aquadest dengan perbandingan $1: 1$ (1 gram ekstrak ke dalam $1 \mathrm{ml}$ aquadest).
C. Penetapan Kadar Kolesterol Darah Tikus

Penetapan kadar kolesterol total, HDL dan LDL dilakukan dengan metoda Spektrofotometri dengan menggunakan KIT kolesterol (CHOD - PAP kolesterol).

\section{Analisis Statistik}

Data diolah dengan menggunakan Anova satu jalan dan dilanjutkan dengan Post Hoc Test jika bermakna

\section{HASIL}

Telah dilakukan penelitian eksperimental tentang pengaruh pemberian ekstrak pepaya terhadap kadar kolesterol total, LDL dan HDL tikus putih jantan hiperkolesterolemia. Penelitian ini dilakukan di Laboratorium Fakultas Farmasi Universitas Andalas pada September - November 2010 dengan hasil sebagai berikut

Tabel 1. Rerata kadar kolesterol total, LDL dan HDL dari serum tikus setelah diinduksi dengan kuning telur selama 15 hari.

\begin{tabular}{cccc}
\hline Perlakuan & \multicolumn{3}{c}{ Hasil pengukuran } \\
\cline { 2 - 4 } & $\begin{array}{c}\text { Kolesterol total } \\
(\mathbf{m g} / \mathbf{d l})\end{array}$ & $\begin{array}{c}\text { HDL kolesterol } \\
\text { (mg/dl) }\end{array}$ & $\begin{array}{c}\text { LDL kolesterol } \\
(\mathbf{m g} / \mathbf{d l})\end{array}$ \\
\hline K & 92,2 & 53,2 & 126,6 \\
P1 & 100,8 & 55,4 & 149,2 \\
P2 & 101,4 & 59,4 & 152,2 \\
P3 & 100,0 & 56,6 & 142,4 \\
\hline
\end{tabular}

$\mathrm{K}=$ kontrol, $\mathrm{P} 1=$ perlakuan $1, \mathrm{P} 2=$ perlakuan $2, \mathrm{P} 3=$ perlakuan 3

Tabel 1 di atas menunjukan bahwa rerata kadar kolesterol total, HDL, dan LDL pada serum tikus yang diinduksi dengan kuning telur adalah 98,60 mg/dl, 56,15 mg/dl, dan $107 \mathrm{mg} / \mathrm{dl}$, duapuluh tikus yang dinduksi dengan kuning telur menunjukan hiperkolesterolemia (kadar kolesterol total tikus > 54,0 mg/dl).

Kadar rerata kolesterol total serum tikus yang diukur sebelum dan sesudah pemberian ekstrak pepaya dicantumkan pada tabel 2. 
Tabel 2. Rerata kadar kolesterol sebelum dan sesudah pemberian ekstrak pepaya

\begin{tabular}{ccccc}
\hline Kelompok & $\mathbf{N}$ & $\begin{array}{c}\text { Rerata kadar } \\
\text { kolesterol total } \\
\text { sebelum pemberian } \\
\text { ekstrak pepaya } \\
\text { (mg/d) }\end{array}$ & $\begin{array}{c}\text { Rerata kadar } \\
\text { kolesterol total } \\
\text { sesudah pemberian } \\
\text { ekstrak pepaya }\end{array}$ & p \\
(mg/dl) & \\
\hline Kontrol (K) & 5 & 92,2 & 95 & 0.178 \\
Dosis 0,5 ml (P1) & 5 & 100,8 & 63,0 & 0,0005 \\
Dosis 1 ml (P2) & 5 & 101,4 & 61,2 & 0,002 \\
Dosis 1,5 ml (P3) & 5 & 100,0 & 69,0 & 0,019 \\
\hline
\end{tabular}

Tabel 2 di atas memperlihatkan $(\mathrm{p}<0,05)$ antara kelompok sebelum dan adanya peningkatan kadar kolesterol sesudah diberi ekstrak papaya.

total secara tidak bermakna $(p>0,05) \quad$ Kadar rerata HDL serum tikus pada kelompok kontrol, sedangkan pada yang diukur sebelum dan sesudah semua kelompok perlakuan (P1, P2, P3) pemberian ekstrak pepaya dicantumkan memperlihatkan penurunan kadar pada tabel 3.

kolesterol total secara bermakna

Tabel 3. Rerata kadar HDL sebelum dan sesudah pemberian ekstrak pepaya

\begin{tabular}{ccccc}
\hline Kelompok & N & $\begin{array}{c}\text { Rerata kadar HDL } \\
\text { sebelum pemberian } \\
\text { ekstrak pepaya } \\
\text { (mg/dl) }\end{array}$ & $\begin{array}{c}\text { Rerata kadar HDL } \\
\text { sesudah pemberian } \\
\text { ekstrak pepaya } \\
\text { (mg/dl) }\end{array}$ & n \\
\hline Kontrol (K) & 5 & 53,2 & 63,4 & 0,080 \\
Dosis 0,5 m 1(P1) & 5 & 55,4 & 93,6 & 0,0005 \\
Dosis 1 ml (P2) & 5 & 59,4 & 93,4 & 0,002 \\
Dosis 1,5 ml (P3) & 5 & 56,6 & 81,2 & 0,003 \\
\hline
\end{tabular}

Tabel 3 di atas memperlihatkan kelompok sebelum dan sesudah diberi adanya peningkatan kadar HDL secara ekstrak papaya.

tidak bermakna $(\mathrm{p}>0,05)$ pada Kadar LDL serum tikus yang kelompok kontrol, sedangkan pada diukur sebelum dan sesudah pemberian semua kelompok perlakuan (P1, P2, P3) ekstrak papaya dicantumkan pada tabel memperlihatkan peningkatan kadar 4.

HDL secara bermakna $(p<0,05)$ antara

Tabel 4. Rerata kadar LDL sebelum dan sesudah pemberian ekstrak pepaya

\begin{tabular}{ccccc}
\hline Kelompok & N & $\begin{array}{c}\text { Rerata kadar LDL } \\
\text { sebelum pemberian } \\
\text { ekstrak papaya }(\mathbf{m g} / \mathbf{d l})\end{array}$ & $\begin{array}{c}\text { Rerata kadar LDL } \\
\text { sesudah pemberian } \\
\text { ekstrak papaya } \\
(\mathbf{m g} / \mathbf{d l})\end{array}$ & $\mathbf{p}$ \\
\hline Kontrol (K) & 5 & 126,6 & 128,8 & 0,537 \\
Dosis $0,5 \mathrm{ml}(\mathrm{P} 1)$ & 5 & 149,2 & 108,8 & 0,026 \\
Dosis $1 \mathrm{ml}(\mathrm{P} 2)$ & 5 & 152,2 & 113,6 & 0,018 \\
Dosis 1,5 ml (P3) & 5 & 142,4 & 110,2 & 0,006 \\
\hline
\end{tabular}


Tabel 4. di atas memperlihatkan adanya peningkatan kadar LDL secara tidak bermakna $\quad(\mathrm{p}>0,05)$ pada kelompok kontrol, sedangkan pada semua kelompok perlakuan (P1, P2, P3) memperlihatkan penurunan kadar LDL secara bermakna $(\mathrm{p}<0,05)$ antara kelompok sebelum dan sesudah diberi ekstrak pepaya.
Tabel 5. Rerata kadar kolesterol total $(\mathrm{mg} / \mathrm{dl})$ hewan coba setelah pemberian ekstrak pepaya

\begin{tabular}{cccc}
\hline $\begin{array}{c}\text { Kelompok } \\
\text { (N=5) }\end{array}$ & Rerata & SD & P \\
\hline I (K) & 95,0 & 8,5 & 0,0005 \\
II (P1) & 63,0 & 6,9 & \\
III (P2) & 61,2 & 4,5 & \\
IV (P3) & 69,0 & 9,5 & \\
\hline
\end{tabular}

Tabel 5 memperlihatkan adanya penurunan rerata kolesterol total secara bermakna $(\mathrm{p}<0,05)$ antara kelompok kontrol (K) terhadap kelompok perlakuan (P1, P2, P3) setelah pemberian ekstrak pepaya.

Tabel 6. Analisis Post Hoc Tests antar kelompok terhadap kadar kolesterol total setelah pemberian ekstrak pepaya

\begin{tabular}{cccc}
\hline Variabel & Kelompok & Kelompok & p \\
\hline & & & \\
Kadar kolesterol & I (K) & II (P1) & 0,0005 \\
setelah pemberian & & III (P2) & 0,0005 \\
ekstrak pepaya & II (P1) & IV (P3) & 0,0005 \\
& & III (P2) & 1,000 \\
& III (P2) & IV (P3) & 1,000 \\
& & IV (P3) & 0,746 \\
\hline
\end{tabular}

Tabel 6 menunjukan bahwa kadar kelompok perlakuan dengan ekstrak kolesterol total antara kelompok $K$ pepaya yaitu antara kelompok P1 (0,5 (kontrol) terhadap kelompok P1 $(0,5 \mathrm{ml})$, P2 $(1 \mathrm{ml})$ dan kelompok P3 (1,5 $\mathrm{ml})$, kelompok P2 $(1 \mathrm{ml})$ dan kelompok $\mathrm{ml})$ menunjukan tidak adanya P3 (1,5 ml) menunjukan perbedaan perbedaan yang bermakna $(p>0,05)$. yang bermakna $(\mathrm{p}<0,05)$. Pada

Tabel 7. Rerata kadar HDL (mg/dl) hewan coba setelah pemberian ekstrak pepaya

\begin{tabular}{cccc}
\hline $\begin{array}{c}\text { Kelompok } \\
\text { (N=5) }\end{array}$ & Rerata & SD & p \\
\hline I (K) & 63,4 & 9,0 & 0,0005 \\
II (P1) & 93,6 & 3,6 & \\
III (P2) & 93,4 & 2,9 & \\
IV (P3) & 81,2 & 8,9 & \\
\hline
\end{tabular}


Tabel 7 memperlihatkan adanya kenaikan kadar HDL antara kelompok kontrol (K) dengan kelompok yang diberi ekstrak pepaya (P1, P2, P3) secara bermakna $(\mathrm{p}<0,05)$.

Tabel 8. Analisis Post Hoc Tests antar kelompok terhadap kadar HDL setelah diberi ekstrak pepaya

\begin{tabular}{cccc}
\hline Variabel & Kelompok & Kelompok & p \\
\hline & & & \\
I (K) & II (P1) & 0,0005 \\
Kadar HDL & & III (P2) & 0,0005 \\
setelah pemberian & II (P1) & IV (P3) & 0,004 \\
ekstrak pepaya & & III (P2) & 1,000 \\
& III (P2) & IV (P3) & 0,060 \\
& & IV (P3) & 0,670 \\
\hline
\end{tabular}

Tabel 8 menunjukan bahwa kadar HDL antara kelompok K (kontrol) terhadap kelompok P1 $(0,5 \mathrm{ml})$, kelompok P2 (1 ml) dan kelompok P3 $(1,5 \mathrm{ml})$ menunjukan perbedaan yang bermakna $(\mathrm{p}<0,05)$. Pada kelompok perlakuan dengan ekstrak pepaya yaitu antara kelompok P1 (0,5 ml), P2 (1 ml) dan kelompok P3 (1,5 ml) menunjukan tidak adanya perbedaan yang bermakna $(\mathrm{p}>0,05)$.
Tabel 9. Rerata kadar LDL (mg/dl) hewan coba setelah pemberian ekstrak pepaya

\begin{tabular}{cccc}
\hline $\begin{array}{c}\text { Kelompok } \\
(\mathbf{N}=5)\end{array}$ & Rerata & SD & p \\
\hline I (K) & 128,8 & 9,5 & 0,002 \\
II (P1) & 108,8 & 6,7 & \\
III (P2) & 113,6 & 5,8 & \\
IV (P3) & 110,2 & 6,5 & \\
\hline
\end{tabular}

Tabel 9 memperlihatkan adanya penurunan kadar LDL antara kelompok kontrol (K) dengan kelompok yang diberi ekstrak pepaya (P1, P2, P3) secara bermakna $(\mathrm{p}<0,05)$

Tabel 10. Analisis Post Hoc Tests antar kelompok terhadap kadar LDL setelah diberi ekstrak pepaya

\begin{tabular}{cccc}
\hline Variabel & Kelompok & Kelompok & p \\
\hline Kadar LDL & I (K) & II (P1) & 0,002 \\
setelah & & III (P2) & 0,027 \\
pemberian & & IV (P3) & 0,006 \\
ekstrak & II (P1) & III (P2) & 1,000 \\
pepaya & & IV (P3) & 1,000 \\
& III (P2) & IV (P3) & 1,000 \\
\hline
\end{tabular}

Tabel 10 menunjukan bahwa $\mathrm{ml})$, kelompok P2 $(1 \mathrm{ml})$ dan kelompok kadar LDL antara kelompok $\mathrm{K}$ P3 $(1,5 \mathrm{ml})$ menunjukan perbedaan (kontrol) terhadap kelompok P1 $(0,5$ yang bermakna $(\mathrm{p}<0,05)$. Pada kelom- 
pok perlakuan dengan ekstrak pepaya yaitu antara kelompok P1 $(0,5 \mathrm{ml}), \mathrm{P} 2$ (1 ml) dan kelompok P3 (1,5 ml) menunjukan tidak adanya perbedaan yang bermakna $(p>0,05)$.

\section{PEMBAHASAN}

Penelitian ini menggunakan 20 ekor tikus putih hiperkolesterolemia yang telah diinduksi dengan kuning telur $2 \mathrm{ml} / 200 \mathrm{~g} \mathrm{BB}$ dan selama 15 hari dibagi menjadi empat kelompok, yaitu kelompok kontrol (K), kelompok yang diberi ekstrak pepaya $0,5 \mathrm{ml}(\mathrm{P} 1), 1 \mathrm{ml}$ (P2) dan 1,5 ml (P3) selama 15 hari berturut-turut.

Hasil analisis uji $\mathrm{T}$ memperlihatkan terjadinya penurunan kadar kolesterol total dan kadar LDL serum pada tikus secara bermakna antara kelompok sebelum dan sesudah diberi ekstrak papaya dengan dosis 0,5 $\mathrm{ml}, 1 \mathrm{ml}$, dan $1,5 \mathrm{ml}$ per $200 \mathrm{~g} \mathrm{BB}$, sebaliknya pemberian ekstrak pepaya menunjukan kenaikan kadar HDL serum pada tikus secara bermakna.

Penurunan kadar kolesterol total pada serum tikus yang diberi ekstrak pepaya membuktikan adanya pengaruh pektin pepaya terhadap penurunan kadar kolesterol total. Hal ini disebabkan terjadinya eliminasi kolesterol dari tubuh dalam bentuk asam empedu oleh pektin dan mengakibatkan tubuh menggunakan kolesterol dalam darah untuk menggantikan asam empedu yang hilang. ${ }^{(5)}$

Sebaliknya, penurunan kolesterol total akan meningkatkan HDLkolesterol yang disebabkan karena penyerapan kolesterol dalam jaringan tubuh yang meningkat. Peningkatan HDL dalam plasma darah terjadi melalui pengikatan kolesterol bebas maupun ester kolesteril Tingginya kadar HDL dalam darah akan mempercepat proses pengangkutan kolesterol ke hati, sehingga mengurangi kemungkinan terjadinya penimbunan kolesterol dalam pembuluh darah. ${ }^{(8,9)}$

Menurunnya kadar asam empedu diusus menyebabkan sintasis asam empedu di jaringan (sel hati) meningkat sehingga VLDL yang terbentuk lebih sedikit. Karena LDL disintesis dari VLDL, maka menurunnya VLDL akan menyebabkan menurunnya kadar IDL, sehingga LDL yang terbentuk juga sedikit. Hal inilah yang dapat menyebabkan turunnya kadar LDL dalam darah. Menurut Fernandez

(1995) bahwa serat pektin dapat meningkatkan FCR (fractional catabolic rate) LDL. ${ }^{(10)}$

Analisis Post Hoc Test menunjukan bahwa terjadi penurunan kadar kolesterol total dan LDL secara bermakna antara kelompok kontrol dengan kelompok yang diberi dosis 0,5 $\mathrm{ml}, 1 \mathrm{ml}$, dan $1,5 \mathrm{ml}$ per $200 \mathrm{~g} \mathrm{BB}$, tetapi tidak terjadi perbedaan yang bermakna antara kelompok perlakuan dosis $0,5 \mathrm{ml} / 200 \mathrm{gBB}$ dengan kelompok dosis $1 \mathrm{ml}$, dan $1,5 \mathrm{ml}$ per $200 \mathrm{gBB}$. Peningkatan kadar HDL terjadi secara bermakna antara kelompok kontrol dengan kelompok yang diberi dosis 0,5 $\mathrm{ml}, 1 \mathrm{ml}$, dan $1,5 \mathrm{ml}$ per $200 \mathrm{~g} \mathrm{BB}$, tetapi tidak terjadi perbedaan yang bermakna antara kelompok perlakuan dosis $0,5 \mathrm{ml} / 200 \mathrm{gBB}$ dengan kelompok dosis $1 \mathrm{ml}$, dan $1,5 \mathrm{ml}$ per $200 \mathrm{gBB}$. Hal ini disebabkan pada kelompok kontrol tidak ada serat pektin yang akan mengikat asam empedu, sehingga tidak terjadi eliminasi asam empedu melalui feses. Sedangkan pada kelompok perlakuan dengan adanya serat pektin akan terjadi pengikatan asam empedu sehingga terjadi eliminasi asam empedu. Namun pemberian ekstrak pepaya antara dosis $0,5 \mathrm{ml}$ dengan $1 \mathrm{ml}$, dan $1,5 \mathrm{ml}$ per $200 \mathrm{~g}$ BB tidak 
memperlihatkan perbedaan yang bermakna. Hal ini disebabkan karena tidak adanya perbedaan pengikatan asam empedu oleh serat pektin antara kelompok yang diberi dosis $0,5 \mathrm{ml}, 1$ $\mathrm{ml}$, dan $1,5 \mathrm{ml}$ per $200 \mathrm{~g}$ BB.

\section{KESIMPULAN}

Dari hasil penelitian tentang efek pemberian jus pepaya terhadap penurunan kadar kolesterol tikus putih yang diberi diet lemak tinggi yang telah dilakukan di Laboratorium Kimia Fakultas Universitas Andalas diperoleh kesimpulan sebagai berikut :

1. Pemberian ekstrak pepaya dapat menurunkan kadar kolesterol total dan LDL serta dapat meningkatkan kadar HDL serum pada tikus putih jantan hiperkolesterolemia

2. Pemberian ekstrak pepaya antara kelompok yang diberi dosis $0,5 \mathrm{ml}, 1 \mathrm{ml}$ dan $1,5 \mathrm{ml}$ per $200 \mathrm{~g} / \mathrm{BB}$ tidak menunjukan perbedaan terhadap kadar kolesterol total, HDL dan LDL serum pada tikus putih jantan hiperkolesterolemia

\section{KEPUSTAKAAN}

1. Zilva, JF \& Pannall, PR ; 1979 ; Clinical Chemistry in Diagnosis and Treatment ; third edition, Year Book Publisher, Inc, Chicago.

2. Wijayakusumah, H.; 2007 ; Ramuam Tradisional Untuk Pengobatan Darah Tinggi; Penebar Swadaya, Jakarta.
3. Kumalaningsih, S.; 2008 ; Antioksidan, Sumber dan Manfaatnya http://wordpress.com/2008/02/2 8/papaya/antioksidansumber\&menfaatnya, diakses tanggal 29/05/08.

4. Linder M.C., 1992, Biokimia Nutrisi Dan Metabolisme, Penerjemah Aminuddin Parrakkasi, Penerbit UI Press, Jakarta.

5. Olwin N, Cornelis A, 2005. Diet Sehat dengan Serat: Cermin Dunia Kedokteran No 147. pp 45-46. Jakarta : Pusat Penelitian dan Pengembangan Pemberantasan Penyakit Badan Penelitian dan Pengembangan Kesehatan, Departemen Kesehatan RI.

6. Kelly, JJ. \& Tsai, AG.; 1978; Effect of Pectin, GumArabic and Agar on Cholesterol Absorption, Synthesis and Turnover Rat; J. Nutr.; 108 : 630-9.

7. Kusumawati D, 2004. Bersahabat dengan Hewan Coba. Fakultas Kedokteran Hewan: Universitas Airlangga.

8. Wirahadikusumah, 1985, Biokimia : Metabolisme Energi, karbohidrat, dan Lipid, Penerbit ITB, Bandung.

9. Mayes, PA.; 1985, Lipid in Harper's Review of Biochemistry; $20^{\text {th }}$ ed. Lange Medical Publication, USA; diterjemahkan oleh Darmawan I; Penerbit EGC, Jakarta. 
10. Fernandez, M. L., 1995, Distinct mechanisms of plasma LDL lowering by dietary fiber in the guinea pig : spesific effects of pectin, guar gum, and psyllium, J. Lipid Res. 36 : 2394-2404. 